\title{
Povos tradicionais, áreas protegidas, turismo e políticas públicas: o papel emergente da academia
}

An emerging role for academia in bridging the disconnect between traditional people, protected areas, tourism and public policy Puebles tradicionales, áreas protegidas, turismo y políticas públicas: el papel emergente de la academia http://dx.doi.org/10.18472/cvt.18n3.2018.1524

Laura Sinay 〈lsinay@usc.edu.au > Universidade Federal do Estado do Rio de Janeiro (Unirio), Rio de Janeiro, RJ, Brasil

Rodney William Carter〈bcarter@usc.edu.au >

University of the Sunshine Coast, Austrália

Maria Cristina Fogliatti de Sinay 〈cristinasinay@gmail.com >

Universidade do Grande Rio (Unigranrio), Rio de Janeiro, RJ, Brasil

CRONOLOGIA DO PROCESSO EDITORIAL

Recebimento do artigo: 07-dez-2017

Aceite: $10-$ dez-2018

FORMATO PARA CITAÇÃO DESTE ARTIGO

SINAY, L.; CARTER, R. W.; SINAY, M. C. F. de. An emerging role for academia in bridging the disconnect between traditional people, protected areas, tourism and public policy. Caderno Virtual de Turismo. Dossiê temático Turismo, Natureza e Cultura: diálogos interdisciplinares e políticas públicas. Rio de Janeiro, v. 18, n. 3, p. 6-22, dez. 2018.

REALIZAÇÃO

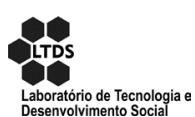

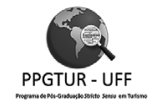

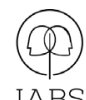

APOIO INSTITUCIONAL

EDIÇÃO

PATROCÍNIO

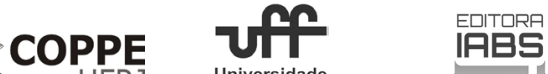

UFRJ Universidade

Fluminense

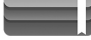

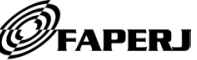




\section{RESUMO}

Este artigo descreve o processo de mudança cultural de uma comunidade tradicional brasileira, os Caiçaras de Martin de Sá, desde o estabelecimento do Sistema Nacional de Unidades de Conservação e o início da chegada de turistas (2000 a 2017). Faz isso com o intuito de analisar: (1) a conexão entre a natureza e a cultura nas políticas públicas, e (2) o diálogo entre a Academia e a gestão pública. O artigo conclui que a conexão entre natureza e cultura foi legalmente reconhecida em algumas áreas protegidas do Brasil por meio da Lei Federal no 9.985/2000. Apesar disso, diversos interesses econômicos, como o agronegócio por exemplo, ainda vulnerabilizam o vínculo entre a natureza e as comunidades tradicionais. Nesse contexto, a Academia tem um importante papel na crítica de políticas públicas, podendo dar suporte aos gestores de áreas protegidas no sentido de maximizar a flexibilidade de instrumentos de políticas de nível inferior. No entanto, no Brasil, a sustentabilidade dos ambientes prístinos e de culturas tradicionais requer políticas que considerem mais amplamente o uso tradicional dos recursos naturais e que empoderem as comunidades tradicionais.

Palavras chave: Áreas protegidas. Comunidades tradicionais. Turismo. Mudança cultural. Políticas públicas. Academia.

\section{ABSTRACT}

This paper describes the process of cultural change in one Brazilian traditional community, the Caiçaras of Martin de Sá, since the establishment of the National System of Protected Areas, and the beginning of tourist arrivals (2000 to 2017). It reviews the research in the context of: (1) reconnecting nature and culture in public policy, and (2) how to promote dialogue between academia and public management. It concludes that nature and culture were notionally reconnected in some of Brazil's protected areas through Federal Law No. 9.985/2000. However, the nature-culture link of traditional communities continues to be vulnerable due economic development interests, especially agribusiness. In this context, academics can take a greater role in critiquing public policy. Informed dialogue between academia and public land managers can be a first step in reconnecting nature and cultures by maximizing flexibility within lower level policy instruments. However, in Brazil, the sustainability of pristine environments and their dependent traditional cultures requires policies that more broadly consider traditional use of natural resources and empower traditional communities.

Keywords: Protected areas. Traditional peoples. Tourism. Cultural change. Policies. Academia.

\section{RESUMEN}

Este artículo describe el proceso de cambio cultural de una comunidad tradicional brasileña, los Caiçaras de Martin de Sá, desde el establecimiento del Sistema Nacional de Áreas Protegidas y el inicio de la llegada de turistas (2000 a 2017). Esto se hace con el fin de analizar: (1) la conexión entre la naturaleza y la cultura en las políticas públicas, y (2) el diálogo entre el mundo académico y la administración pública. Concluye que la conexión entre naturaleza y cultura fue legalmente reconocida en algunas áreas protegidas de Brasil a través de la Ley Federal no 9.985/2000. A pesar de ello, diversos intereses económicos, como el agronegocio por ejemplo, aún vulnerabilizan el vínculo entre naturaleza y comunidades tradicionales. En este contexto, la Académia tiene un importante papel en la crítica de políticas públicas, pudiendo dar soporte a los gestores de áreas protegidas para maximizar la flexibilidad de instrumentos de políticas de nivel inferior. Sin embargo, en Brasil, todavía son necesárias políticas que consideren más ampliamente el uso tradicional de los recursos naturales y que empoderen a las comunidades tradicionales.

Palavras clave: Áreas protegidas. Comunidades tradicionales. Turismo cultural. Políticas públicas. Academia 


\section{INTRODUCTION}

It is commonly accepted that criteria used to assess the performance of academic institutions are teaching, research and service to the community (PORTNOI et al., 2010). Internally, tertiary education institutions seek to align these key performance indicators in the interests of efficiency and developing standing nationally and internationally (PORTNOI et al., 2010). Similarly, they seek to provide service through knowledge and understanding transfer based on disciplined research, especially unbiased interpretation, extrapolation and application of empirical data. Herein lies a role for academics that goes beyond the teaching of students to include community education and informing public policy for improved decisionmaking. However, the making of public policy and its application is not the domain of the academic, and separation of these roles is important for maintaining the independence of academia to inform, advice and critique governance and management. The emergence of policy discourse within academia is exemplified by journals addressing policy implications of science within almost all discipline areas, but especially the social and management sciences; so much so, that policy and governance research attracts their own methodological and analytical peer-reviewed journals, these are necessary as the issues addressed are embedded on moral values.

Public policy discourse related to the interaction of traditional peoples, protected areas and tourism is well-developed, i.e. they exist and are on place, where indigenous and traditional people are modernizing, but less so where such people remain living their traditional lifestyles. Concern for the disempowerment of these people and loss of cultures has not been reflected in the number of studies in such societies. Hence, countries with indigenous populations living traditional, subsistence lifestyles in natural areas tend to be subject to policies adopted from quite different circumstances. This is the case in Brazil, where conservation obligations are met through protected area establishment that overlays the traditional lands of Indigenous peoples. Confounding the issues that arise is the increasing demand for tourist use of protected areas and indeed cultural tourism, where experiencing intact traditional cultures is the goal. Apart from ethical considerations, how to manage the disparate interests of stakeholders, including economic development of communities of place and interest (SINAY, 2008), remains problematic for managing authorities ${ }^{1}$, and policy makers.

In this paper, we describe the process of change, and its influential factors, in one Brazilian traditional community, Martin de Sa, since enactment of the Brazilian Federal Law No. 9.985/2000 (LF 9.985/00), which established the National System for Conservation Units (SNUC). It also covers the time from the beginning of tourist arrivals (i.e., 2000 - 2017). We seek to demonstrate how policy, its interpretation, and its interaction with other stressors can affect traditional indigenous communities, and how longitudinal monitoring ${ }^{2}$ of community dynamics and change might inform policy interpretation and application in specific contexts. However, it will be evident from the case study that while dialogue between academic researchers, the community and some other stakeholders was enriched, interaction with managers and policy makers remained remote, with objectives for resource management being only slowly achieved and with conflict. We use the case study to identify how academia might provide service to key stakeholders through iterative monitoring of policy implementation and recording affected community response to management and outsider action.

\footnotetext{
${ }^{1}$ Which includes "anyone with the power or right to give orders, make decisions, and enforce obedience" (DICTIONARY, 2008)

${ }^{2}$ As described in section A longitudinal study of cultural change in a protected area context - methodology
} 


\section{INDIGENOUS COMMUNITIES, CULTURE AND PROTECTED AREAS}

\section{CULTURE, CHANGE AND TRADITIONAL PEOPLE}

'Culture' refers to the totality of mental and physical reactions and activities that characterize the behavior of individuals in relation to their natural environment, to other groups, to members of the group itself and to themselves (BOAS, 1965). This includes all knowledge, beliefs, morals, laws, art, customs, other expressions and habits acquired by people as members of a society, as well as products of human activity and their role in the life of groups. It refers to the perceptions and standards by which people see cultural resources, traditions, and expressions. It is a trait possessed by every person, learnt from living within a community; it is a framework for interpreting and responding to experiences of the world. By inventions and discoveries, individuals are continually adding knowledge to culture. Hence, cultures are constantly changing (LEVI-STRAUSS, 1958-1973).

Worldwide there are about 370 million traditional peoples (AMNESTY INTERNATIONAL, 2015). They inhabit all continents (except Antarctica) and most terrestrial ecosystems (SINAY, 2008). Each has their own traditions, religion, cuisine, dress, arts, language, laws, and way of explaining life (BOEDHIHARTONO, 2017). They often live in small communities, based on some form of kinships linkage (DIEGUES, 1994). Many make decisions by consensus or general agreement and do not have any centralized state organization (JONES et al., 1992). Order is internally maintained through tradition, lore and systems of sanction and reward. Externally imposed laws, regulations and policies of modern society often challenge the culturally determined systems of governance.

Most semi-isolated traditional communities have low levels of production and low inputs. Their unique systems of thought and values and their largely self-sufficient, closed economy (MENDES, 2015) separates them from many other cultural groups and modern society. This is usually associated with a profound association with the land in which they live, which is often held to be sacred (KEMF, 1993). Many traditional communities live wholly or partly on gathering plants, hunting or fishing (TOURNEAU; BEAUFORT, 2017). This close link with nature is often the first to be broken as traditional communities enter the consumer society.

Traditional cultures maintaining their integrity tend to remain separate from urban industrial society, preserving their systems of thought and values (ASANTE et al. 2017), although this is changing as contact with Western cultures becomes more frequent (SINAY, 2002, 2008). As a result, most traditional cultures are changing rapidly, rather than through a gradual process within which change can be accommodated (SINAY, 2002, 2008).

While change is an inherent and inevitable characteristic of culture, globalization forces are affecting multiple cultural expressions concurrently. The web of cultural expression (see CARTER; BEETON, 2004) is under constant stress with no time to stabilize, and communities are losing the capacity to manage their change process. Cultures tend to collapse and are absorbed into the dominant culture; individuals are dislocated spatially, socially and culturally. For traditional people under globalization pressures, few individuals have prospered. The majority has suffered land alienation, high rates of unemployment, extreme poverty, oppression and violence (SINAY, 2008; AMNESTY INTERNATIONAL, 2015).

Brazilian traditional peoples are no exception and are at risk of being absorbed into the dominant cultural at the expense of their own. While less than half of Brazil's traditional people live in areas where 
cultural practices are legally protected, the remainder struggle to sustain their cultures (lifestyle and traditions) in the context of growth and expansion of non-traditional populations and economies or within the expansion of protected areas.

\section{ACKNOWLEDGING THE IMPORTANCE OF TRADITIONAL PEOPLE IN THE CONSERVATION OF PROTECTED AREAS}

Indigenous and traditional peoples are also known as 'ecosystem people' as they "depend on functioning ecosystems for survival" (IUCN, 2016). The interdependency and stewardship results in the bestpreserved natural areas occurring on customary lands (IUCN, 2016), which extend to about 65 per cent of the world's terrestrial surface (RIGHTS AND RESOURCES INITIATIVE, 2015). In this context, it makes no sense to "talk about conservation without speaking of Indigenous Peoples and their role as the guardians of our most delicate lands and waters" (IUCN, 2016).

Traditional peoples' roles in conservation were first recognized by the International Union for the Conservation of Nature (IUCN) in 1948 through the nomenclature of Anthropological Reserves, and ratified in 1994 within Category VI: Protected area with sustainable use of natural resources. However, despite this recognition of the conservation importance of Indigenous and traditional peoples' occupation and management of traditional lands, both nature and the protective traditional practices are being lost (MINORITY RIGHTS, 2016), through exploitive interests and land management that usurps customary practices. Consequently, it is expected that in the next century at least 50 per cent (and up to 90\%) of existing Indigenous languages and associated accumulated knowledge will be lost (MINORITY RIGHTS, 2016).

Brazil shelters at least 500,000 traditional people. While some are nomadic and have little contact with other cultural groups (FUNDAÇÃO NACIONAL DO ÍNDIO, 2017), most live in settlements (INSTITUTO SOCIOAMBIENTAL, 2017), many of which are associated with protected areas. These often include significant reserves of valuable minerals (e.g., gold, copper, oil), sites for dam construction projects and production of energy, as well as areas attractive for agribusiness expansion. As a result, conflict over land rights often results (INSTITUTO SOCIOAMBIENTAL, 2017). These conflicts, obviously, need to be avoided.

\section{THE DISCONNECT BETWEEN BRAZILIAN PROTECTED AREA MANAGEMENT POLICY AND INDIGENOUS COMMUNITIES}

Despite previous laws, before passing LF 9.985/00, Brazilian protected areas were managed based on the idea that, since people destroy nature (MELLO et al., 2014), any community living within a protected area must be removed (CUNHA; COELHO, 2003). This paradigm brought serious challenges in achieving the dual objectives of nature and cultural protection. Most pristine areas in Brazil (and in many other parts of the world) are inhabited by traditional peoples, whose livelihoods are based on subsistence activities, practiced for millennia. Human occupation of the conserved lands is an integral part of the ecological systems. As moving entire communities was not possible, the solution was to tolerate the presence of traditional peoples, but activities such as cropping, harvesting, hunting and fishing, which deemed exploitive of nature, and hence prohibited. This made the survival of traditional subsistence communities an impossibility within protected areas. In practice, policy was differentially applied, except within high profile, highly visited protected areas. 
While, in the name of nature conservation, customary practices were being curtailed and traditional cultures being made vulnerable, Western people's interest in them and in pristine areas grew, as did the number of tourists seeking to visit these areas. Facing the risk of forced removal or chronic food insecurity, many traditional people migrated, often to the outskirts of cities. Those that remained often engaged in tourism activities to replace loss of income generated through subsistence activities. Thus, emigration, economic activity prohibitions and tourism have led to altered cultural practices within communities living in protected areas (SINAY, 2008). Failure to monitor change in populations, livelihoods and cultural practices meant that some cultures effectively disappeared, almost unnoticed.

In response, FL 9.985/2000 created a new protected area category that did not necessitate the removal of subsistence people. This category, which is subdivided in seven sub-categories, focuses on the sustainable use of natural resources as the main strategy for nature conservation (cf., PELLIZZARO, 2015). Sustainable use is allowed provided it does not interfere with the renewal of resources and ecological processes (BRAZIL, 2000). With this, the rights, knowledge and way of living of traditional peoples were legally recognized as important for the conservation of nature, and the permanent occupation of designated protected areas by traditional people was permitted. It was believed that this Act would protect traditional customs of people living within protected areas and minimize unwanted cultural change. In turn, traditional practice would be maintained and with it the ecological processes that have included the influence of people as part of the processes; thereby conserving nature. However, LF 9.985/00 did not grant land ownership to traditional peoples occupying the protected area.

While the governance process for accommodating traditional peoples within the protected area concept was established, it required those living within protected areas to establish standing as traditional peoples and acknowledgement of their claim over the protected area as a traditional living site ${ }^{3}$. It also required the protected area, established under previous legislation, to be appropriately re-designated. This proved to be particularly difficult for those non-Indigenous cultural groups caught in the process of change, but without knowledge of how to negotiate standing and re-designation of the category of protected area necessary for their traditional occupation of the land.

\section{A LONGITUDINAL STUDY OF CULTURAL CHANGE IN A PROTECTED AREA CONTEXT - METHODOLOGY}

The research initially sought to model cultural change in a neo-traditional subsistence community under the pressure to change from tourism within a protected area. What resulted was a 17 -year longitudinal study of change to one community and response to pressures from within and outside the community and contemporary policy affecting the management of the protected area. The study adopted a grounded theory methodology (see GLASER; STRAUSS, 1967) to build the model of cultural change based on the perspectives of informants (SINAY et al., 2008). This was deemed important because cultural change depends on local factors such as the culture's resistance and resilience, pressures and management responses (CARTER; BEETON, 2008). Hence, grounded data were considered more reflective of the unusual phenomenon being studied and expected to generate a social, psychological and logical

${ }^{3}$ From the year 2000, when the law was stablished, to now other approaches were introduced as dis-affectation, re-categorization, relocations and double affectation. 
understanding of the process of cultural change. Following this methodology, changes and causes identified are based on informants' constructions, not on existing theories of cultural change. Informants were asked if they observed cultural changes (no explanations were given regarding what cultural change is). Those that observed changes were asked to explain what changed, what caused change and the consequences of the observed changes ${ }^{4}$.

The Caiçara community at Martin de Sá (Paraty, Rio de Janeiro, Brazil) was selected for study because they were: (1) only recently influenced by contemporary pressures, (2) a neo-traditional community, (3) occupying a protected area, (4) undergoing significant cultural change, and (5) accessible and familiar to the researcher so that available time could be used for maximum data collection.

This study developed through four stages. Over the 17 years of data collection, more than 450 interviews were conducted. The first stage started three months before the establishment of FL 9.985/00, in March 2000, until 2002. Twelve Caiçaras of the local community and 50 tourists were engaged in situ with semi-structured interviews with open-ended questions. These participants were consulted subsequently several more times through unstructured interviews. Semi-structured interviews were also held with managers (i.e., representatives of the Environment Institute of Rio de Janeiro State (INEA) and a local NGO (Green Citizenship) who had an established interest in management of the reserve and the rights of the Caiçaras. Interviews revealed the community's history, the history of the place, expectations about the future, pressures influencing cultural change, tourism characteristics and possible management interventions (SINAY, 2002).

During the second stage, from 2004 to 2008, 81 Caiçaras from 12 communities within the same protected area as Martin de Sá, 74 tourists from five tourism destinations within the same area, four managers of the protected area and nine representatives of the local NGO were interviewed.

The third stage took place during 2015. Individual responses to closed-ended questions, based on the initial interviews, were gathered on-line from tourists, representatives of INEA and the local NGO. Selfvolunteering respondents were accessed through Facebook@ advertising and the mailing list of the Park Project, which includes research that aims to contribute to the sustainability of the protected areas of Rio de Janeiro and had, at the time, 1300 contacts. By May 2015, 225 on-line surveys were completed. The synthesis of these results was presented to the community for validation and used for discussing cultural change. Except for the eldest woman (who was 110 years old at the time), all remaining adult members of the Martin de Sá community participated (three men, including the community leader, and two women).

During the fourth stage, face-to-face structured interviews with closed-ended questions were used for the 46 tourists who visited Martin de Sá between 16 and 20 January 2017, and face-to-face individual semi-structured interviews with open-ended questions were used with the 17 adult Caiçaras who were in Martin de Sá during the same period (the elder community member previously mentioned had passed away in 2016). Interview questions were based on those asked during previous stages, which again aimed to clarify the demographic profile of tourists, and their motivations and activities while at Martin de Sá, especially interaction with the Caiçaras, as well as perceptions of cultural and environmental changes and management interventions. A synthesis of results was again presented to the community for validation and again stimulated discussions about cultural change. All Caiçaras, adult and children, present at the time at Martin de Sá participated in this part of the research.

\footnotetext{
${ }^{4}$ For detailed information, please refer to (SINAY, 2008).
} 


\section{CULTURAL CHANGE WITHIN THE CAIÇARA COMMUNITY OF MARTIN DE SÁ}

\section{THE CAIÇARA COMMUNITY OF MARTIN DE SÁ}

The Caiçara community at Martin de Sá lives within the Juatinga Ecological Reserve to the south of Rio de Janeiro state (Figure 1), in the Paraty municipality. The reserve is part of one of the most wellpreserved areas of Atlantic Forest and shelters the small, but regionally important Caiçara community.

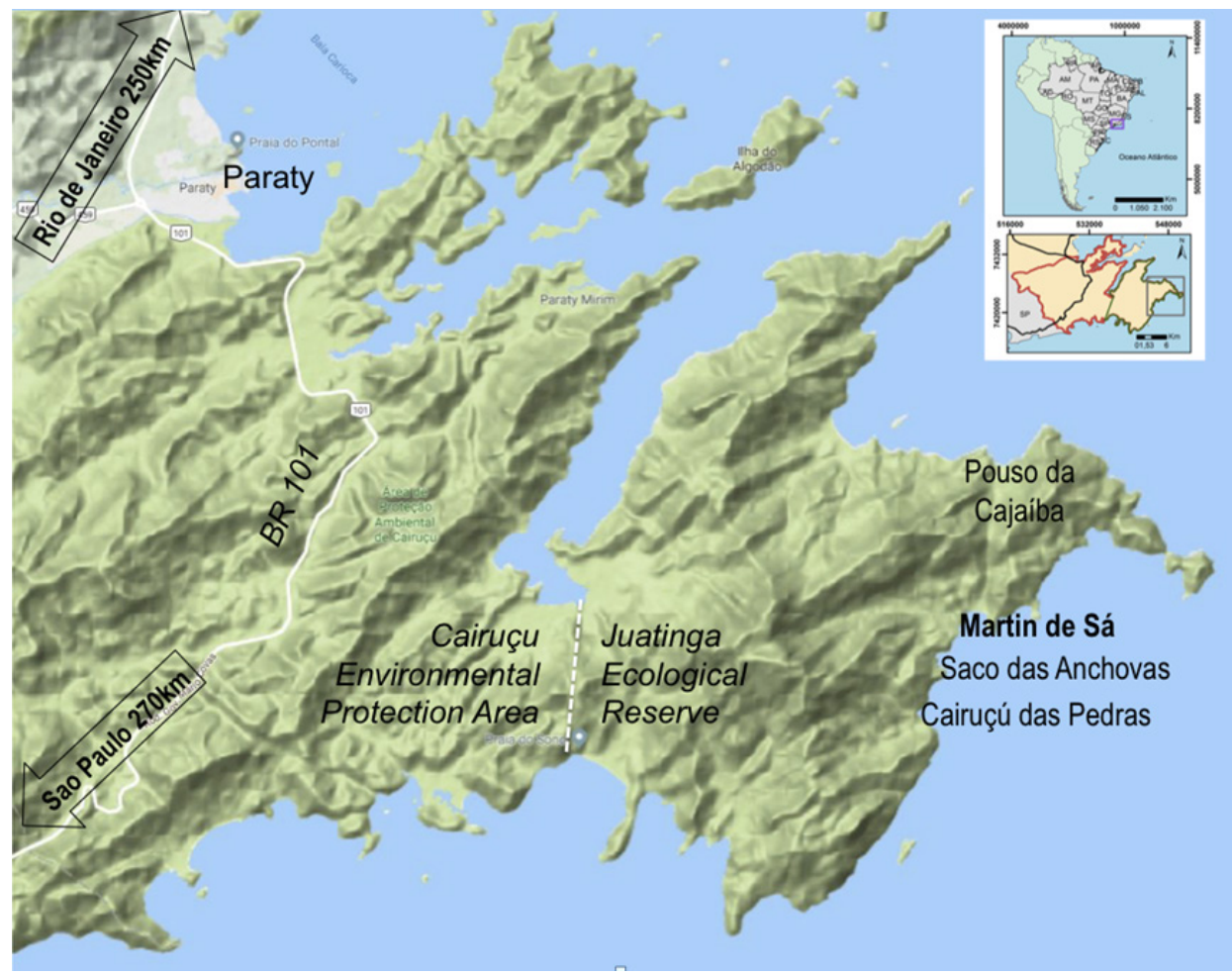

Figure 1 - Location of Caiçara communities within the Ecological Reserve Juatinga

Traditionally, the studied Caiçaras periodically change their place of residence as a strategy to use natural resources sustainably. Hence, community boundaries are not only dependent on the place where the individuals live, but on their perceptions of belonging and their ancestral roots. While not permanent inhabitants, about 30 Caiçaras identify themselves as part of the Martin de Sá community. They represent four generations of one family and frequently come and go, to and from Martin de Sá.

Caiçaras explain that the union of indigenous people, fugitive slaves (Africans), pirates and colonizers are their ancestors, each contributing to their traditional culture. They are, therefore, partly aboriginal, as are many Brazilians. The main difference between the Caiçara people and the rest of the Brazilian society is that their isolation has led to the retention of traces of their indigenous and African ancestral cultures. With this, the environment where they have lived for centuries is conserved. 
Fishing was the Caiçaras' most important subsistence activity, so most communities are located close to calm water beaches, easily accessible by traditional canoes. A difference between the Martin de Sá Caiçaras community and others is that they have been more isolated from contemporary influences. At Martin de Sá, the shore break is usually of dangerously large waves. Therefore, use of traditional canoes and fishing boats was difficult and hazardous, which restricted access to a two-hour walking path from the nearest Caiçara community (Pouso da Cajaíba), from where it is possible to travel by sea to the nearest town, Paraty; a three-hour journey in traditional canoes.

From a globalization perspective, the history of Paraty can be divided into four periods. The first starts with its first inhabitants and ends with the arrival of colonizers ( $16^{\text {th }}$ century). During this period, various indigenous groups inhabited permanently or temporarily (nomads) the region. The second period, from the $17^{\text {th }}$ to the $18^{\text {th }}$ century, is characterized by colonization and the establishment of one of the most important ports of the time at Paraty. From there, significant amounts of gold and sugarcane were exported to Europe. The third period commences with the creation of a Royal Road connecting sugarcane plantations and mines to Rio de Janeiro, where a better port was built, and ends in the 1970s. During this period, Paraty's economic importance declined and the area again became isolated. As a result, aboriginal cultures flourished and new traditional cultures emerged, including the Caiçara culture. These were mainly formed from the miscegenation of Indigenous people with African and /or Europeans who remained in the area ${ }^{5}$. The fourth and current period, started in the 1970s with the construction of a national road (BR-101) that connects Paraty to Rio de Janeiro and São Paulo. This can be described as the tourism and protected area period.

According to Caiçara oral history, the first tourists arrived in the 1970s, disrupting the long semiisolation period of Martin de Sá. This tourism period did not last long, as one of the first tourists, supported by heavy armaments, established a farm in the area, bringing outsiders to work on the land and enslaving local community members ${ }^{6}$. Knowing the area better than the outsiders, some Caiçaras managed to run away to Cairuçú das Pedras and Saco das Anchovas (Figure 1), where they continued performing their traditional activities, while maintaining a connection to Martin de Sá. About a decade later, the farm became economically unviable and was abandoned, and in the early 1990s, some Caiçaras returned to re-establish their traditional way of life.

Apart from customary governance, the Martin de Sá area was a lawless frontier where power determined relationships between outsiders and the traditional communities. Many community members were displaced, but traditional ties to the land remained and cultural practices continued.

\section{PROTECTED AREA ESTABLISHMENT AS A FORCE FOR CONFLICT}

While Caiçaras were returning to Martin de Sá, their customary lands and those of 11 other Caiçara communities became legally protected under the State Act 17,981/1992 through establishment of the Juatinga Ecological Reserve. Although there was virtually no budget and only one person to manage the Reserve's 10,000 hectares, the Act effectively transferred responsibility for managing the land from the Caiçaras to INEA (the State Environmental Institute and agency of the Government of the State of Rio de Janeiro). This resulted in a top-down management approach that prohibited development. Under the Act,

5 Information collected in field.

${ }^{6}$ Information collected in field. 
INEA was required to prepare specific programs for the sustainable use of natural resources, but this was never done. All Caiçaras' traditional subsistence activities and tourism were prohibited, and traditional ownership strongly contested and extinguished. This greatly affected all Caiçara communities living in the Reserve. They were viewed as criminals and intruders on their customary lands, but access difficulties, and INEA's lack of a boat and fuel, meant that the Martin de Sá community was little affected by conservation rules until the 2000s.

In 2000, two of the 12 Caiçara communities were nearly extinct: one was displaced by the construction of high-class tourists' second homes, with Caiçaras working as laborers (e.g., gardeners and cleaners). For the other community, all except two Caiçaras were violently banished. Those who remained in the Reserve were fearful and suspicious of INEA, of land speculators, and of tourists and tourism impacts. This was the situation when the FL 9.985/00 was declared and the rights of traditional peoples could be legally recognized.

As Ecological Reserves are not recognized by the provisions of FL 9.985/00, it was expected that the Reserve would been reclassified by 18 July 2002 to recognize Caiçara traditional occupation, and address problems associated with land tenure, natural resources use and visitation. The reclassification and planning processes, as legally defined, needed to be participatory. So, especially from 2000 to 2002, INEA frequently called community meetings to discuss which of the twelve categories of protected area might be appropriate for the Reserve. They publicly advocated that local natural resources should not be used and, if possible, local communities should be displaced. Without understanding of Caiçara history with the Reserve area, INEA's starting point was that FL 9.985/00 should not be applied, the Reserve should be retained as an ecological reserve, and that the Caiçaras had no standing as a traditional culture living a subsistence lifestyle on reserve natural resources. In contrast, the Caiçaras wanted their rights recognized, land tenure secured, speculation controlled, and tourism organized. Opposing perspectives, fueled by a history of conflict and the absence of appropriate mediation, transformed these meetings into open conflicts and no consensus was reached.

Seventeen years after the establishment of the FL 9.985/00, there is still no consensus regarding the recategorization of the Reserve, or about conservation and development rules. Management continues to be top down, traditional subsistence activities continue to be prohibited, construction permits still depend on a manager's whim, and land tenure is uncertain. The Caiçaras illegally and surreptitiously maintain customary use of Reserve resources, with considerable pressure to cease such activities and migrate from the Reserve.

\section{RESOLVING OUTSIDER LAND CLAIMS, BUT NOT THOSE OF THE CAIÇARAS}

The Caiçaras of Martin Sá struggled to remain on their customary lands not only because of the preservationist environmental policy being applied, but also due to land disputes with the farmer's family, who, years after abandoning the farm, reclaimed the land to transform it into a tourism resort. After nearly a decade of dispute, in 2012 a committee formed by three judges arbitrated over the case.

During the 10 days that preceded the hearing, Green Citizenship, a local non-governmental organization, organized a manifest and 10,000 people signed an online petition asking that the traditional rights of the Caiçaras be acknowledged. On 12 June 2012, while about 200 people wearing traditional 
dress and playing traditional drums protested in front of the Rio de Janeiro City Forum, the committee denied the farmer's claim over Martin de Sá in recognition of the ecological values of the Reserve, and by inference, informally acknowledged Caiçara claims. However, land conflicts continue between community members and between the community and INEA, which tolerates the Caiçaras only if they do not use natural resources in line with the Reserve's continuing ecological designation.

\section{RAPID MODERNIZATION OF CAIÇARA LIFESTYLE AND THE ADVENT OF TOURISM}

At the time FL 9.985/00 was passed in 2000, 30 years after Martin de Sá isolation was first disrupted, Caiçaras were still living traditionally: hunting, fishing, cropping and harvesting, with nearly no contact with the outside world. Evangelical Christians brought the main changes to the culture. During the following years, tourism and implementation of ecological reserve policy became the main drivers of change, along with a decline in fish stock. Adoption of the Western education was gradual, but by 2017, most of the children were attending school in Paraty, and no longer lived permanently in Martin de Sá. There are, however, children who remain illiterate.

The embracing of Western technology was rapid, and by 2006, most of the traditional canoes were replaced by aluminum motorboats, which decreased travel time from and to Paraty from five hours to 45 minutes. This allowed the incorporation of (super) markets into daily life. Also, by 2017 , except for the two oldest people, all community members had mobile phones or tablets and most had Facebook accounts (even though there was no mobile signal at Martin de Sá). From 2010, solar panels were installed and, in 2015, they were producing sufficient energy to maintain freezers and a couple of lamps per house.

While hunter-tourists commenced visiting Martin de Sá during the 1970s, tourism flow ceased during the farming period and slowly recommenced during the 1990s, despite the absence of tourism infrastructure. Around 1995, the first Caiçara house was rebuilt and camper tourists could count on the assistance of locals. Tourist numbers grew from about 150 in 2000 to around 6,000 in 2016. They come mostly from Rio de Janeiro and São Paulo and are, either attending university, if they are first time visitors, or are graduates, if they are repeat visitors.

Even with the significant growth in tourism flow, for the Caiçaras, tourism represents a phenomenon that is opportunistically responded to. As of 2017, there is no official plan for tourism development and management, no official marketing, and little accommodation or infrastructure.

Despite their continued relative isolation, the Caiçaras living at Martin de Sá were not immune to changes brought by improving access to modern commercial services, technology and the demonstration effect (SEATON, 1996) of tourists. Servicing tourists became a cash income source for the community to buy modern products and gain an education for children, while subsistence livelihoods remained the principal means of survival, supplemented by some wholesale fishing sales. 


\section{PERCEPTIONS OF CULTURAL CHANGES}

In 2017, about 12 per cent of the interviewed tourists perceived cultural change ${ }^{7}$. Of these, all described changes to Caiçara traditional economy, and 60 per cent expressed concern for migration. Fourteen per cent perceived environmental change ${ }^{8}$ : decline in fish stock, reduced encounters with wild animals, and lower water level in the nearby rivers.

In both 2015 and 2017, all the interviewed Caiçaras perceived cultural and environmental changes. The latter was commonly represented by reduced encounters with wild animals, and the former identified as changes to non-material culture, that began from 2000. Most commonly reported, and starting before 2000, were concerns for the way community members were relating to the land, which traditionally was considered sacred. Land speculation and land ownership/rights created conflict, put a price on nature, which became a commodity. Since 2012, when the Judicial Court decision favored the Caiçaras ${ }^{9}$, it seems that these understandings merged, and land and nature became sacred commodities.

Also considered to be significant was INEA's imposition of official ambassadors to represent each community during the re-categorization attempts. Traditionally, the community leader was either the oldest or the person recognized by other community members as the chief. Most of the traditional leaders were illiterate. Ignoring the existence of these authentic representatives, in 2000, INEA appointed 'ambassadors' that were capable of writing, reading and signing accords. Generally, the literate Caiçaras were one generation younger than traditional leaders and had lived for long periods in cities, usually Paraty. They had gained a modern education, but had lost much Caiçara' traditional knowledge. Without a choice, and in disregard of the traditional decision-making process, Caiçaras responded to the appointment by reorganizing their social structure. One of the daughters of the original leader, who lived in Paraty, became the official ambassador of Martin de Sá. This change lasted only a couple of years and soon the traditional leader regained his chief status.

Tourism too was reported as affecting Caiçaras' traditional social structure. With historic isolation, many community members initially did not interact with tourists. As soon as visitors arrived, most would hide inside their homes or undertake their livelihood activities out of tourist eyesight. A demand for, and opportunity to provide tourist services emerged. The community leader responded by organizing tourism activities and centralizing income from the provision of services, without community distribution. Women cooked and cleaned, but were not paid. This changed when the wife of the community leader asked for divorce. She built, with the help of her sons, a house and started to use her porch as a restaurant. Following her example, some daughters and sons did the same; others negotiated other activities, such as selling fish and transporting tourists. By 2015, the community leader continued to control most of the tourist income-earning activities, but not all.

Flowing from other changes was a loss in the collective response of the community to perturbations. While isolated and having a subsistence lifestyle, Caiçaras needed to rely on each other: a bad year or a bad crop could mean deprivation for all. Thus, altruism and sharing was the key to survival. As the economy

\footnotetext{
7 The majority (70\%) had visited Martin de Sá more than four times.

$860 \%$ had visited Martin de Sá more than four times.

${ }^{9}$ For more information, please refer to the section Resolving outsider land claims, but not those of the Caiçaras.
} 
changed and access to markets became easier, community disagreements intensified and selfishness grew. While Caiçara informants only began to describe this change in 2015, all mentioned it and considered it to be a significant change in their culture.

In 2015, a son of the community leader moved with his family to a slum in Angra dos Reis. There, he became involved with criminals. In January 2016, he returned with four of his allies and assaulted Martin de Sá community members and tourists. All tourists were robbed and most of the community members were held hostage, except for the community leader, who was at sea fishing, and children who could evade capture. The criminals unsuccessfully searched for money expected to be hidden by the community leader. They awaited his return with the plan to execute him to inherit the land. The news of the assault, however, spread rapidly, and the village chief and police were notified in time to catch the criminals who are now in jail. The aggressive occupation of the village lasted only an hour, but for the first time, the isolation of Martin de Sá became a recognized concern and vulnerability of the community.

Following the assault, most of the community openly identified a desire to move to a safer place. In response, Green Citizenship and the Federal University of the Rio de Janeiro State, held community debates to discuss how they could improve tourism management, diminish resentments and better share tourism's responsibilities and revenues. Six months later, Caiçaras had developed a plan, which included the retirement of the community leader in 2018, with his sons and daughters collectively being appointed to be responsible for managing tourism.

\section{DISCUSSION - RECONNECTING NATURE AND CULTURE, AND THE ROLE OF PUBLIC POLICY}

Eighteen years of academic monitoring of cultural change in the case of the Caiçaras of Martin de Sá indicates the progressive disconnect between nature and culture. While public policy relating to protected area management is not the sole factor influencing change, it appears to have been a foundation for exposing the vulnerability of the Caiçaras to change, and reducing the resistance of the community to other change pressures. It also precipitated community migration, reducing the number of community members practicing traditional cultural expressions and hence reducing any inherent resilience within the community (CARTER; BEETON, 2008). The precipitating factors were protected area policy that included a tenet that nature conservation cannot occur in the presence of human communities; irrespective of whether they are living a subsistence existence or not. The opportunity to mitigate the disconnect between culture and nature was lost with the delay in re-designating the protected area to permit subsistence activity. The delay, and continual top-down management determined to maintain the ecological reserve concept, meant that the community had to shift a subsistence lifestyle to a cash economy. In a modest way, the Caiçaras joined the tourism economy and with it came other pressures to drive cultural change. The community lost the capacity to manage change processes and sustain cultural expressions that linked nature and culture.

The study identified change as it occurred and the factors driving change, as well as those that could possibly instill resistance and resilience to cultural change. However, policy and legal institutions prevented the Caiçaras from expressing agency. This was only achieved through educated surrogates, not members of the community, who brought the case in front of the authorities. 


\section{RECONNECTING NATURE AND CULTURE THROUGH PUBLIC POLICY}

Nature and traditional cultures are open to reconnection in Brazil, at least in some protected areas, through FL 9.985/00. The desirability of maintaining connections and restoring disconnections has been promulgated in international forums since 1948. The problem with Brazilian policy is that it is narrowly focused on tenure rather than resources, and gaining standing as a traditional subsistence community is difficult. This remains a problem for 'new world' countries where Indigenous communities have been displaced and their land and resource use rights have been usurped in favor of economic growth. More holistic approaches and models exist in New Zealand, Canada and to a lesser extent Australia, where consideration of traditional indigenous rights is enshrined in most resource management acts, including those relating to protected areas where co-management is becoming a minimum approach. The inherent consistency in these initiatives lies in not being prescriptive, acknowledging that context, communities and cultural aspirations differ. While these models are not without their critics, they tend to acknowledge customary use of resources as a starting point and then seek to encourage interaction between stakeholders to find appropriate balances between traditional and contemporary use. The main difficulty remains in who ultimately has the authority and responsibility to manage.

Half of the Brazilian parliament is part of the 'rural front' (REED; FONTANA, 2017), which aims to stimulate the expansion of public policies for the development of national agribusiness (FRENTE PARLAMENTAR RURALISTA, 2014). Their stated priorities include the modernization of regulations regarding "indigenous and quilombolas lands, in order to guarantee the necessary legal security to the competitiveness of the sector" (FRENTE PARLAMENTAR RURALISTA, 2017). With this political agenda, Indigenous and traditional peoples' rights are being jeopardized, both by interpretations of both new and old policies. This suggests that achieving the goal of reconnecting nature and culture for traditional communities will be made more difficult. International approaches demonstrate the value in not reducing Indigenous rights, but rather extending them beyond the protected area approach to nature conservation, to embrace resource use more broadly.

To reconnect nature and culture in public policy requires identifying the nature and extent of the disconnect, as well as the maintained connections and the stakeholders involved. Different communities will have different perspectives on their cultural and livelihood links with nature. What becomes important for informing policy is how connectedness is expressed by different cultures, how the connect is maintained and disconnection occurs, how policy fosters disconnection, or encourages maintenance of connection. Addressing these questions is an appropriate role for disinterested and independent academics who can provide data to facilitate evidence-based policy making.

\section{CONCLUSION - THE ROLE OF THE ACADEMIC}

Boyer (1990) proposed a new (at the time) understanding of what scholarship means. He challenged whether the attention being given to research was affecting the quality of teaching and whether it was addressing issues relevant to communities supporting the research institution. He proposed that lecturing, research and social engagement should be developed together. That is, lecturers should teach the same issues they research and should involve students in social engagement projects that give something back to society, as well as relate knowledge to the real world. This is now largely adopted in tertiary education and research institutions around the world. The mandate for academics to engage 
in policy dialogue exists, the desirability of shifting to evidence-based policy making is demonstrable, yet the case study demonstrates that engagement with managers was insufficient to address issues in Martin de Sá. There was a need to change, or interpret differently, public policy to meet the peculiar circumstances in the reserve.

Policy makers are largely notoriously loathe to change policy unless political risk is low and the probability of achieving desired outcomes are enhanced by adopting new directions. This is also the case for managers charged with implementing policy. The challenge for academics then is to undertake research that provides evidence that different actions can achieve better outcomes. We propose six considerations that need to be foremost in negotiations with policy makers and managers when undertaking research that impinges on policy. These are based on reflection on our research with the Caiçaras.

- 1. Have data, not opinion (leave that to the politicians) - advise policy makers and managers of the data and its implications (public exposure of poor policy should be the last resort).

- 2. Seek to address questions policy makers and managers want answered - they will normally be responsive to international obligations, maintenance of law and order, and demonstrable achievement of improved outcomes.

- 3. Engage with communities undergoing change early, monitor change and divergence from desired outcomes, and gain community agreement on these.

- 4. Ensure appreciation by all stakeholders that policy exists in a hierarchy from the constitution, laws influenced by international agreements, regulations and expressed as plans (and other instruments) for implementation through agencies (public or private). This is important because effort can be wasted addressing issues at the wrong policy level.

- 5. Appreciate that policy development and implementation needs community support, especially affected community support; therefore, they must be engaged.

- 6. Academics, as a disinterested group, can provide the needed data and facilitation; but their results must be reviewed dispassionately.

\section{REFERENCES}

AMNESTY INTERNATIONAL. Indigenous peoples. Available at: 〈https://www.amnesty.org/en/whatwe-do/indigenous-peoples/>. Cited o4 nov. 2016.

ASANTE, E. A.; ABAIO, S.; BOADU, K. B. The Use of Indigenous Cultural Practices by the Ashantis for the Conservation of Forests in Ghana. In: Traditional Wisdom. SAGE Open. January-March 2017. p. 1-7. 2017.

BOAS, F. The mind of primitive man. New York: Free Press, 1965.

BOEDHIHARTONO, A. K. Can Community Forests Be Compatible With Biodiversity Conservation in Indonesia? In: Land. v. 6, n. 1, 2017.

BOYER, E. L. 1990, Scholarship Reconsidered: priorities of the Professoriate. Special Report, Carnegie Foundation for the Advancement of Teaching. New York: Jossey-Bass.

BRASIL. Lei Federal N. 9.985 (LF 9.985/oo), de 18 de Julho de 2000. Sistema Nacional de Unidades de Conservação da Natureza. Brasília, DF, 2000. 
CARTER, R. W.; BEETON, R. J. S. A Model of Cultural Change and Tourism. Asia Pacific Journal of Tourism Research, v. 9, n. 4, p. 423-442, 2004.

CARTER, R. W.; BEETON, R. J. S. Managing Cultural Change and Tourism: a review and perspective. In: PRIDEAUX, B.; Timothy, D. J.; Chon, K. (Ed.). Cultural and Heritage Tourism in Asia and the Pacific, 1st ed., p. 134-156. London: Routledge. 2008.

CUNHA, L. H.; COELhO, M. C. N. Política e Gestão Ambiental. In: GUERRA, A. T.; CUNHA, S. B. (Org.). A questão ambiental: diferentes abordagens. Rio de Janeiro: Bertrand Brazil, 2003.

DICTIONARY, O. E. Oxford English Dictionary. Retrieved May, 30, 2008.

DIEGUES, A. 0 mito moderno da natureza intocada. São Paulo: Hucitec Annablume NUPAUB, USP, 1994. FRENTE PARLAMENTAR DA AGROPECUÁRIA. (n.d.). Histórico. Retrieved 26-10-2017 from http://www. fpagropecuaria.org.br/fpa.

FRENTE PARLAMENTAR DA AGROPECUÁRIA. (02-04-2014). Estatuto. Retrieved 2017 йил 29-11 from http://www.fpagropecuaria.org.br/estatuto.

FUNDAÇÃO NACIONAL DO ÍNDIO. (n.d.). Povos Indígenas Isolados e de Recente Contato. Retrieved 10 26, 2017 from http://www.funai.gov.br/index.php/nossas-acoes/povos-indigenas-isolados-e-derecente-contato.

GLASER, B.; STRAUSS, A. L. The discovery of grounded theory: strategies for qualitative research, Aldire Publishing Co., Chicago, 1967.

INSTITUTO SOCIOAMBIENTAL. Terras Indígenas no Brazil. 2017. Retrieved 10 26, 2017 from https:// terrasindigenas.org.br/pt-br/brasil

IUCN, INTERNATIONAL UNION FOR THE CONSERVATION OF NATURE. Map shows Indigenous peoples as guardians of Central American ecosystems. 2016. Retrieved 10 15, 2017 from https://www.iucn.org/ content/map-shows-indigenous-peoples-guardians-central-american-ecosystems.

IUCN, INTERNATIONAL UNION FOR THE CONSERVATION OF NATURE. World Conservation Congress 2016. Retrieved 10 15, 2017 from Engaging with indigenous rights: https://2016congress.iucn.org/ news/20160808/engaging-indigenous-rights.html.

JONES, S.; MARTIN, R.; PILBEAM, D. The Cambridge encyclopedia of human evolution. Cambridge: Cambridge University Press, 1992.

KEMF, E. The Law of the mother: protecting indigenous peoples in protected areas. San Francisco, California: Sierra Club Books, 1993.

LEVI-STRAUSS, C. Anthropologie structurale. Paris: Plon. 1973.

MENDES, J. F.; PORRO, N. S. M. Social conflicts in times of environmentalism: living law rights to land in settlements with a conservationist focus. Ambiente e Sociedade, on-line, v. 18, n. 2, p. 93-110. 2015.

MORSE, J. Designing funded qualitative research. In: Handbook of qualitative research. Thousand Oaks, California: Virding Astrid, Sage Publications. 1994.

PELLIZZARO, P. C. et al. Stewardship and management of protected natural areas: the international context. Ambiente e Sociedade, on-line. v. 18, n. 1, p. 19-36. 2015.

PORTNOI, L.; RUST, V. D.; BAGLEY, S. Higher education, policy and the global competition phenomenon. New York. Palgrave Macmillan. 2010. 
REED, S.; FONTANA, V. Direitos indígenas esbarram na bancada ruralista. O Globo, set. 2017.

SEATON, G. Tourism and Relative Deprivation: The Counter- Revolutionary Pressures of Tourism in Cuba. In: Tourism and Culture: towards the 21st century, Conference Proceedings, Vol. Tourism and Culture: Image, Identity and Marketing (Eds, Robinson, M., Evans, N. and Callaghan, P.) The Centre for Travel \& Tourism in association with Business Education Publishers Ltd., Sunderland, p. 197-216, 1996.

SINAY, L. Ecoturismo e culturas tradicionais - Estudo de caso: Martin de Sá. Masters Dissertation in Social Ecology - Psychology Institute, Universidade Federal do Rio de Janeiro, Rio de Janeiro. 2002.

Modelling Cultural and Environmental Changes. Dissertation PhD in Natural Resources Management - Natural Resources Management School, The University of Queensland, Queensland. 2008.

Modelling and Forecasting Cultural and Environmental Changes. (PhD). The University of Queensland, Australia. 2008.

SINAY, L.; CARTER, R. W.; SMITH, C. Modelling Indigenous Cultural Change in Protected Areas. In: Monitoring, Simulation and Management of Visitor Landscapes. Arizona press, v. 1, p. 2008.

SURVIVAL INTERNATIONAL. Retrieved 30-10-2017 from The Loggers will wipe out the Indians: https:// www.survivalinternational.org/tribes/kawahiva

TOURNEAU, F. M. T.; BEAUFORT, B. Exploring the boundaries of individual and collective land use management: institutional arrangements in the PAE Chico Mendes (Acre, Brazil). In International Journal of the Commons. v. 11, n. 1, p. 70-96. 2017. 